\title{
Justyna Bocheńska
}

Uniwersytet Marii Curie-Skłodowskiej w Lublinie

j.bochenska94@gmail.com

\section{Umowa przelewu wierzytelności a podatek dochodowy od osób prawnych}

Taxation of Assignment of Receivables with Corporate Income Tax

\section{STRESZCZENIE}

Zagadnienia dotyczące opodatkowania umowy przelewu wierzytelności podatkiem dochodowym od osób prawnych należą do kwestii bardzo istotnych. Sytuacja jest jednak różna w zależności od podmiotów. W przypadku podmiotów, których przedmiotem działalności gospodarczej jest obrót wierzytelnościami, najważniejszą regulacją na gruncie ustawy o podatku dochodowym od osób prawnych, dotyczącą sposobu powstania przychodu, jest art. 12 ust. 3 i 3a, natomiast w przypadku tych, które zbywają wierzytelności własne i nie prowadzą działalności gospodarczej w tym zakresie, jest to art. 14 ust. 1. Tematyka ta jest przedmiotem niejednokrotnie sprzecznych ze sobą orzeczeń i interpretacji sądów administracyjnych, dlatego można uznać, że zagadnienia te, choć istotne, nadal nie są $\mathrm{w}$ pełni uregulowane $\mathrm{w}$ polskim systemie prawnym.

Slowa kluczowe: cesja; wierzytelność; podatek

Analizując zagadnienia dotyczące opodatkowania podatkiem dochodowych od osób prawnych umowy przelewu wierzytelności, należy brać pod uwagę odrębne okoliczności. Z punktu widzenia ustawy o podatku dochodowym od osób prawnych istotne jest, czy przelew wierzytelności dotyczy wierzytelności „,własnych”, które wynikają z „własnych” dokonanych dostaw towarów lub wyświadczonych usług, czy też wierzytelności „obcych”, czyli takich, które zostały wcześniej przez nie nabyte, a które powstały w majątku innego podmiotu ${ }^{1}$.

$\mathrm{Z}$ uwagi na dość skromne regulacje dotyczące tematyki opodatkowania podatkiem dochodowym od osób prawnych umowy przelewu wierzytelności warto skupić się na orzecznictwie Naczelnego Sądu Administracyjnego. Przykładem może

1 R. Jurkiewicz, Wierzytelność i dlug - aspekty prawne i podatkowe, Warszawa 2013, s. 98. 
być wyrok Naczelnego Sądu Administracyjnego II FSK 1948/09 z dnia 22 lutego 2011 r., w którym podkreślono, że zbycie wierzytelności własnej jest odmiennym zdarzeniem niż sprzedaż towaru będąca źródłem powstania tej wierzytelności czy też sprzedaż wierzytelności przez podmiot, dla którego obrót wierzytelnościami stanowi przedmiot działalności gospodarczej. Są to odrębne stany, ponieważ inne są podstawy prawne uzyskanych przychodów we wcześniej wymienionych sytuacjach ${ }^{2}$.

W sytuacji sprzedaży związanej z prowadzoną działalnością gospodarczą, zgodnie z art. 12 ust. 3 ustawy o podatku dochodowym od osób prawnych ${ }^{3}$, przychodem są również przychody należne, nawet jeżeli nie zostały jeszcze otrzymane. Biorąc pod uwagę normę z art. 14 u.p.d.o.p., przychodem będzie cena, którą kontrahent zobowiązał się zapłacić, a przychód ten powstanie zgodnie z ogólną regułą, która dotyczy należności powiązanych z działalnością gospodarczą, tj. w dacie, w której doszło do zbycia prawa majątkowego, ale nie później niż w dniu wystawienia faktury lub uregulowania płatności ${ }^{4}$.

Jako koszt podatkowy należy rozumieć wartość utraconego, przekazanego w zamian za należną zapłatę, prawa majątkowego. Zaistnienie faktu poniesienia kosztu powinno być utożsamione z pozbyciem się tytułu prawnego o określonej wartości i jego przejściem na nabywcę. Zgodnie z art. 15 ust. 4 u.p.d.o.p. jest to koszt bezpośredni, który ma służyć i prowadzić do osiągnięcia przychodu podatkowego $\mathrm{z}$ ceny pochodzącej $\mathrm{z}$ transakcji. $Z$ uwagi na to, że koszty uzyskania przychodu powiązane z przychodami uzyskanymi w danym roku są potrącane w roku podatkowym, w którym zostały uzyskane odpowiadające im przychody, można na tej podstawie ustalić dochód bądź stratę poniesioną na danej transakcji, o ile zapłata ceny i przejście praw do wierzytelności nastąpi w tym samym roku' ${ }^{6}$.

Sprzedaż wierzytelności własnej nie jest sprzedażą związaną z prowadzoną działalnością gospodarczą i stanowi źródło przychodów określonych w art. 12 ust. 1 pkt 1 ustawy o podatku dochodowym od osób prawnych, do którego zastosowanie będzie miał art. 14 ust. 1 u.p.d.o.p., zgodnie z którym przychodem z odpłatnego zbycia rzeczy lub praw majątkowych jest ich wartość wyrażona w cenie określonej w umowie.

Ponadto przychód ze sprzedaży wierzytelności własnej nie został wyłączony z przychodów na podstawie art. 12 ust. 4 u.p.d.o.p. Zgodnie z treścią art. 16 ust. 1 pkt 39 u.p.d.o.p. nie uważa się za koszty uzyskania przychodów strat z tytułu odpłatnego zbycia wierzytelności, chyba że wierzytelność ta uprzednio na podstawie art. 12 ust. 3 u.p.d.o.p. została zakwalifikowana jako przychód należny. Dlatego należy zauważyć,

2 Wyrok NSA z dnia 22 lutego 2011 r, sygn. II FSK 1948/09.

3 Ustawa z dnia 15 lutego 1992 r. o podatku dochodowym od osób prawnych (Dz.U. z 1992 r., nr 21, poz. 86), dalej jako: u.p.d.o.p.

4 U. Lewińska, T. Lenart, Skutki podatkowe wybranych czynności bankowych, Warszawa 2013, s. 293.

5 Ibidem.

6 Ibidem. 
że następuje tu wyłączenie z kosztów uzyskania przychodów określonego zdarzenia prawnego, nie dochodzi jednak do modyfikacji ogólnej zasady, która określa co jest, a co nie jest kosztem uzyskania przychodów w podatku dochodowym od osób prawnych. Zasada ta jest zawarta w art. 15 ust. 1 u.p.d.o.p. i na jej podstawie dany wydatek kwalifikowany jest jako koszt uzyskania przychodów. Na podstawie art. 16 ust. 1 pkt 39 u.p.d.o.p. należy zwrócić uwagę, że wyłączenie określonego wydatku z kosztów uzyskania przychodów zgodnie z art. 15 ust. 1 u.p.d.o.p. powoduje, że nie stanowi on kosztu uzyskania przychodów, podobnie jak brak takiego wyłączenia na podstawie art. 16 ust. 1 u.p.d.o.p. Dopiero po spełnieniu przesłanek określonych w art. 15 ust. 1 u.p.d.o.p. istnieje podstawa do uznania go za koszt podatkowy.

Naczelny Sąd Administracyjny zwraca uwagę na zasadę, zgodnie z którą strat z tytułu odpłatnego zbycia wierzytelności nie uważa się za koszty uzyskania przychodów. Istnieje jednak wyjątek, zgodnie z którym kosztem uzyskania przychodów może być strata z tytułu odpłatnego zbycia wierzytelności, jeżeli wierzytelność ta uprzednio, na podstawie art. 12 ust. 3 u.p.d.o.p., została zaliczona jako przychód należny. Ustawodawca dokonał podziału na wierzytelności zbyte, które zostały uprzednio zarachowane na podstawie art. 12 ust. 3 u.p.d.o.p. jako przychód należny, oraz zbycie innych wierzytelności. Jedynie w pierwszym przypadku strata, która powstała przy zbyciu wierzytelności, może stanowić koszt uzyskania przychodów. O tym, czy będzie stanowiła koszt podatkowy i w jakiej wysokości, decyduje treść art. 15 ust. 1 u.p.d.o.p.

Nie zawsze podatnik jest uprawniony do rozpoznania całej wartości sprzedawanego prawa majątkowego jako kosztu ${ }^{7}$ Wątpliwości może budzić treść art. 16 ust. 1 pkt 39 u.p.d.o.p., ponieważ nie jest do końca przejrzyste sformułowanie: „nie uważa się za koszty uzyskania przychodu strat". Można je pojmować w dwojaki sposób: 1) jako koszt uzyskania przychodu powinna być ujmowana tylko ujemna różnica między ceną zbycia a wartością nominalną zbywanych wierzytelności, 2) należy odrębnie przyjąć i wykazać przychód ze zbycia wierzytelności, a odrębnie koszt podatkowy stanowiący wartość nominalną zbywanej wierzytelności ${ }^{8}$. Trzeba zauważyć, że słowo „uprzednio” użyte w art. 16 ust. 1 pkt 39 u.p.d.o.p. powinno się odnosić do źródła powstania należności, a nie momentu czasowego uzyskania tego przychodu. Owym źródłem powstającej należności jest przychód powiązany z prowadzeniem działalności gospodarczej lub działami specjalnymi produkcji rolnej. W przeciwnym razie nie ma możliwości jego zaliczenia do przychodów należnych na podstawie art. 12 ust. 3 u.p.d.o.p. Biorąc pod uwagę koszty uzyskania przychodów z tytułu zbycia wierzytelności własnej, nie ma znaczenia, że wierzytelność ta uprzednio została zarachowana w kwocie netto, z pominięciem należnego podatku od towarów i usług na podstawie art. 12 ust. 4 pkt 9 u.p.d.o.p.

7 Ibidem, s. 294.

8 R. Jurkiewicz, op. cit., s. 98. 
Warto zwrócić uwagę na istniejącą znaczącą różnicę między „wierzytelnością” a ,przychodem należnym”. Wierzytelność, oprócz przychodu należnego, obejmuje również podatek VAT. Z uwagi na treść art. 16 ust. 1 pkt 39 u.p.d.o.p. źródło wierzytelności, która jest przedmiotem umowy sprzedaży, ma być w prowadzonej przez podatnika działalności gospodarczej. Uznanie straty z odpłatnego zbycia wierzytelności za koszt podatkowy zostało uzależnione od uprzedniego zarachowania jej do przychodu należnego na podstawie art. 12 ust. 3 u.p.d.o.p. Nie jest jednak określone, co w przypadku jej zbycia jest kosztem podatkowym: wierzytelność, która obejmuje całą kwotę należności, czy przychód należny z tej wierzytelności. Biorąc pod uwagę wykładnię (językową, systemową wewnętrzną, celowościową), należy przyjąć, że kosztem uzyskania przychodów jest wierzytelność, która obejmuje całą kwotę należności wraz z należnym podatkiem od towarów i usług (brutto), ponieważ ta kwota w przypadku zbycia wierzytelności w celu uzyskania przychodów uszczupli majątek. Według Naczelnego Sądu Administracyjnego ${ }^{9}$ nie istnieje uzasadnienie działania organu podatkowego dokonującego wykładni przepisu, która ma na celu doprowadzić do ograniczenia wysokości możliwej do zaliczenia do kosztów uzyskania przychodów straty ze sprzedaży wierzytelności.

Zagadnienia dotyczące opodatkowania podatkiem dochodowym od osób prawnych umowy przelewu wierzytelności należą z pewnością do kwestii, których regulacja prawna w ustawach podatkowych ma skomplikowany i zawiły charakter. Tworzona jest bowiem odmienna sytuacja prawna dla podmiotów, których przedmiotem działalności gospodarczej jest obrót wierzytelnościami oraz tych, które zbywają wierzytelności własne i nie prowadzą działalności gospodarczej w tym zakresie. W pierwszym przypadku najważniejszą regulacją ustawodawcy na gruncie ustawy o podatku dochodowym od osób prawnych, dotyczącą sposobu powstania przychodu, jest art. 12 ust. 3 i 3a, w drugim natomiast jest to art. 14 ust. $1^{10}$. Dochód lub stratę z tytułu sprzedaży wierzytelności wyznacza porównanie ceny ze sprzedaży wierzytelności (jako przychodu) i wartości wierzytelności (jako kosztu uzyskania przychodu) ${ }^{11}$.

${ }^{9}$ Wyrok NSA z dnia 22 lutego 2011 r., II FSK 1948/09.

${ }^{10}$ Wyrok WSA w Rzeszowie z dnia 26 kwietnia 2011 r., I SA/Rz 109/11.

${ }^{11}$ B. Brzeziński, M. Kalinowski, Podatek dochodowy od osób prawnych. Komentarz, Warszawa 1995 , s. 124-125. 
Pobrane z czasopisma Studenckie Zeszyty Naukowe http://szn.umcs.pl

Data: 26/04/2023 11:34:10

Umowa przelewu wierzytelności a podatek dochodowy od osób prawnych

\section{BIBLIOGRAFIA}

Brzeziński B., Kalinowski M., Podatek dochodowy od osób prawnych. Komentarz, Warszawa 1995. Jurkiewicz R., Wierzytelność i dlug - aspekty prawne i podatkowe, Warszawa 2013.

Lewińska U., Lenart T., Skutki podatkowe wybranych czynności bankowych, Warszawa 2013.

Ustawa z dnia 15 lutego 1992 r. o podatku dochodowym od osób prawnych (Dz.U. z 1992 r., nr 21, poz. 86).

Wyrok NSA z dnia 22 lutego 2011 r., II FSK 1948/09.

Wyrok WSA w Rzeszowie z dnia 26 kwietnia 2011 r., I SA/Rz 109/11.

\section{SUMMARY}

Taxation of assignment of receivables with corporate income tax does not have the legislation applied in a uniform manner. Situation is variable due to the subject. The Act of Corporate Income Tax forms different regulations for objects whose assignment of receivables is a subject of business activity and for those whose not. This subject matter become an object of contrary judicial decision and tax interpretations due to incomplete regulations in Polish legal system.

Keywords: taxation; assignment; receivables 